\title{
GCOM-C Data Validation Plan for Land, Atmosphere, Ocean, and Cryosphere
}

\author{
By Masahiro Hori,${ }^{1)}$ Hiroshi MuraKami,${ }^{1)}$ Risa Miyazaki, ${ }^{1)}$ Yoshiaki Honda, ${ }^{2)}$ Kenlo Nasahara, ${ }^{3)}$ Koji Kajtwara, ${ }^{2)}$ \\ Takashi Y. NaKaJIMA, ${ }^{4)}$ Hitoshi IRIE, ${ }^{2)}$ Mitsuhiro Toratani, ${ }^{5)}$ Toru HiRAwaKe, ${ }^{6)}$ and Teruo AOKI ${ }^{7), 8}$ \\ ${ }^{1)}$ Earth Observation Research Center, JAXA, Tsukuba, Japan \\ ${ }^{2)}$ Center for Environmental Remote Sensing, Chiba University, Chiba, Japan \\ ${ }^{3)}$ Graduate School of Life and Environmental Science, The University of Tsukuba, Tsukuba, Japan \\ ${ }^{4)}$ Research and Information Center, Tokai University, Tokyo, Japan \\ ${ }^{5)}$ Department of Optical and Imaging Science and Technology, Tokai University, Hiratsuka, Japan \\ ${ }^{6)}$ Faculty of Fisheries Sciences, Hokkaido University, Hakodate, Japan \\ ${ }^{7)}$ Graduate School of Natural Science and Technology, Okayama University, Okayama, Japan \\ ${ }^{8)}$ Climate Research Department, Meteorological Research Institute, Tsukuba, Japan
}

(Received June 19th, 2017)

\begin{abstract}
Japan Aerospace Exploration Agency (JAXA) will launch an Earth observing satellite for climate studies named "Global Change Observation Mission - Climate (GCOM-C)" in 2017 which carries a multi-spectral optical sensor named Second-Generation Global Imager (SGLI). The GCOM-C satellite will observe various geophysical variables such as vegetation, land surface temperature, aerosol, clouds, ocean color, sea surface temperature, snow cover extent, snow grain size and so on. The objectives of the SGLI observations are to elucidate the roles of the geophysical variables in the recent changing Earth's climate system and to establish long-term satellite data record of the variables. Three kinds of target accuracies to be achieved for the SGLI observations are defined for evaluating the success of the GCOM-C satellite mission. First one is the minimum thresholds to be achieved for the first SGLI data release at one year after the launch of GCOM-C. Second and third thresholds are the standard and goal accuracies to be achieved at five years after the launch for evaluating the full and extra success of the mission. The target accuracies for individual SGLI products are available at the GCOM-C web site (http://suzaku.eorc.jaxa.jp/GCOM_C/index.html). The quality and accuracies of SGLI products are planned to be evaluated and maintained through validation activities organized by the SGLI validation team consisting of JAXA and SGLI principal investigators (PIs). Uncertainties of the SGLI data products will be characterized through the comparison with in-situ observations, similar products derived from other satellites, climatological data, and/or numerical model simulations. This paper summarizes the overall validation plan for the SGLI geophysical variable products.
\end{abstract}

Key Words: GCOM-C, SGLI, Satellite Remote Sensing, Validation, In-situ Measurement

\section{Introduction}

JAXA will launch an Earth observing satellite for climate study named "GCOM-C" in Japanese fiscal year JFY2017 which carries a multi-spectral optical imager SGLI. ${ }^{1)}$ SGLI is a successor of Global Imager (GLI) onboard the Advanced Earth Observing Satellite-II (ADEOS-II) which was launched in December 2002 and unfortunately stopped operation in October 2003. The GCOM-C will observe various geophysical variables $(\mathrm{GVs})$ related to land, atmosphere, ocean, and cryosphere such as vegetation, land surface temperature, aerosol, clouds, ocean color, sea surface temperature, snow cover extent, and snow grain size and so on in order to elucidate their climatic roles and to establish long-term satellite data record of those GVs.

\section{Second Generation Global Imager (SGLI)}

SGLI has 19 spectral channels spanning from near ultra-violet at the wavelength of $380 \mathrm{~nm}$ to thermal infrared at $12 \mu \mathrm{m}$ as shown in Table 1. Signal to noise ratio (SNR) of individual channels are defined at the standard radiance $\left(\mathrm{L}_{\mathrm{std}}\right)$. Both the SNR and the maximum radiance $\left(\mathrm{L}_{\max }\right)$ detectable by
SGLI are determined based on the usage of the channels. Among the SGLI channels VN4, VN6, VN7, and VN10 are high-gain channels with low $\mathrm{L}_{\max }$ designed for the retrieval of ocean color variables such as chlorophyll-a concentration, total suspended matter, and colored dissolved organic matter etc. Spatial resolution (instantaneous field of view (IFOV)) for nadir looking channels of visible to near infrared regions (VN1-VN11) and a shortwave infrared channels SW3 (1.63 $\mu \mathrm{m})$ is $250 \mathrm{~m}$, whereas other shortwave infrared (SW1, 2, 4) and slant-viewing polarization channels (P1-P2) have $1 \mathrm{~km}$ ground resolution. Thermal infrared (TIR) channels (T1-T2) have fine IFOV of $500 \mathrm{~m}$ as standard resolution but optionally SGLI has a capability to acquire $250 \mathrm{~m}$ resolution data for T1-T2 channels. Currently the finer $250 \mathrm{~m}$ resolution data for T1-T2 are planned to be acquired over terrestrial and coastal regions on a global scale, which will be a great advantage of SGLI as global observation sensor for monitoring temperature of spatially heterogeneous surfaces such as terrestrial patchy vegetation, snow, sea ice with low concentration, and coastal water and so on.

One of new features of SGLI is the polarization observation function which enables us to observe the Earth's surface forward or backward at an off-nadir angle of 45-degree at

Copyright $₫ 2018$ by the Japan Society for Aeronautical and Space Sciences and ISTS. All rights reserved. 
three polarization angles ( 0 and \pm 60 deg.). The degree of polarization is useful for retrieving aerosol over land. It is expected that a combination use of the slant-viewing (P1 and P2) and nadir looking (VN8 and VN11) channels, that is, multi-angle observations will also make a roughness estimations of vegetation over land and ice sheet over Greenland and the Antarctica, which will contribute to enhancing the accuracy of the retrieval of biomass and snow physical variables over those regions.

Table 1. SGLI channel specification.

\begin{tabular}{|c|c|c|c|c|c|c|}
\hline \multirow[b]{2}{*}{$\mathrm{CH}$} & $\lambda$ & $\Delta \lambda$ & $\mathrm{L}_{\text {std }}$ & $\mathrm{L}_{\max }$ & $\mathrm{SNR}$ at $\mathrm{L}_{\text {std }}$ & IFOV \\
\hline & \multicolumn{2}{|c|}{$\begin{array}{l}\mathrm{VN}, \mathrm{P}, \mathrm{SW}: \mathrm{nm} \\
\mathrm{T}: \mu \mathrm{m}\end{array}$} & \multicolumn{2}{|c|}{$\begin{array}{l}\mathrm{VN}, \mathrm{P}: \mathrm{W} / \mathrm{m}^{2} / \mathrm{sr} / \mu \mathrm{m} \\
\mathrm{T}: \text { Kelvin }\end{array}$} & $\begin{array}{l}\text { VN, P, SW: -, } \\
\mathrm{T}: \mathrm{NE} \Delta \mathrm{T}\end{array}$ & $\mathrm{m}$ \\
\hline VN1 & 380 & 10 & 60 & 210 & 250 & 250 \\
\hline VN2 & 412 & 10 & 75 & 250 & 400 & 250 \\
\hline VN3 & 443 & 10 & 64 & 400 & 300 & 250 \\
\hline VN4 & 490 & 10 & 53 & $120^{* 1}$ & 400 & 250 \\
\hline VN5 & 530 & 20 & 41 & 350 & 250 & 250 \\
\hline VN6 & 565 & 20 & 33 & $90^{* 1}$ & 400 & 250 \\
\hline VN7 & 673.5 & 20 & 23 & $62^{* 1}$ & 400 & 250 \\
\hline VN8 & 673.5 & 20 & 25 & 210 & 250 & 250 \\
\hline VN9 & 763 & 12 & 40 & 350 & 1200 & $250 / 1000$ \\
\hline VN10 & 868.5 & 20 & 8 & $30^{* 1}$ & 400 & 250 \\
\hline VN11 & 868.5 & 20 & 30 & 300 & 200 & 250 \\
\hline $\mathrm{P} 1$ & 673.5 & 20 & 25 & 250 & 250 & 1000 \\
\hline $\mathrm{P} 2$ & 868.5 & 20 & 30 & 300 & 250 & 1000 \\
\hline SW1 & 1050 & 20 & 57 & 248 & 500 & 1000 \\
\hline SW2 & 1380 & 20 & 8 & 103 & 150 & 1000 \\
\hline SW3 & 1630 & 200 & 3 & 50 & 57 & 250 \\
\hline SW4 & 2210 & 50 & 1.9 & 20 & 211 & 1000 \\
\hline T1 & 10.8 & 0.74 & 300 & 340 & 0.2 & $250 / 500$ \\
\hline $\mathrm{T} 2$ & 12.0 & 0.74 & 300 & 340 & 0.2 & $250 / 500$ \\
\hline
\end{tabular}

*1: VN4, VN6, VN7, and VN10 are high gain channels with lower dynamic range for ocean color.

\section{SGLI Products and Validation}

There are 29 GVs to be retrieved from SGLI-observed radiances (i.e., Level-1) as Level-2 standard products (See Table 2 shown at the end of this paper and also refer to the GCOM-C web ${ }^{2)}$ for the details of the product definitions both for the standard and research products and the algorithm theoretical basis documents (ATBD)). In this section the SGLI Leve- 2 products and the validation strategy for land, atmosphere, ocean, and cryosphere are briefly introduced.

\subsection{Land}

Various land GVs are defined as standard product as shown in Table 2. First two are products for geometric and atmospheric corrections over land (Product ID: LTOA and RSRF). Remaining land GVs except for the last land surface temperature (LST) are vegetation-related products such as vegetation index (VGI), above-ground biomass (AGB), vegetation roughness (VRI), shadow index (SDI), fraction of absorbed photosynthetically active radiation (FPAR), and leaf area index (LAI). The target accuracies for those vegetation-related products are defined for grass and forest regions separately.

The accuracy of the geometric correction is evaluated using ground control points (GCPs) prepared with AVNIR-2 high resolution images. Accuracies of other land products are evaluated primarily based on the comparison with in-situ observed GV data and secondarily on the comparison with similar GV products (if available) derived from other satellite observations by optical images (e.g., MODIS and VIIRS), space-borne lidars (e.g., MOLI and GEDI are under planning), and synthetic aperture radar (SAR) (e.g., PALSAR2). For the in-situ observations of AGB, SDI, LAI, FPAR, and LST we are establishing several super sites in Japan which has at least a $500 \mathrm{~m}$ by $500 \mathrm{~m}$ square uniform field in forest area and thus can provide in-situ derived GVs comparable to SGLI observations with $250 \mathrm{~m}$ spatial resolution. ${ }^{3)}$

\subsection{Atmosphere}

Most of the atmosphere GVs have been handed down from ADEOS-II/GLI mission to GCOM-C/SGLI except for the product of aerosol by polarization (ARPL). The ARPL is a new product to be derived from the SGLI polarization observations. Other cloud and aerosol GVs such as cloud flag/classification (CLFG), classified cloud fraction (CFR), cloud top temperature/height (CLTT, CLTH), water cloud optical thickness/effective radius (COTW, CERW), ice cloud optical thickness (COTI), aerosol over the ocean (AOTO, AAEO), and land aerosol by near ultra violet (AOTL, AAEL) are derived from SGLI observations by non-polarization channels.

Validation of aerosol products are basically conducted through the comparison with in-situ observations of aerosol optical thickness (AOT) obtained from ground observation networks such as the SKYNET ${ }^{4)}$ and AERONET. ${ }^{5)}$ As for the validation of the cloud flag (CLFG) product, the achievement of release threshold (RT) is evaluated comparing with cloud amount estimated from ground based sky-camera images, whereas those of standard accuracy (SA) and target accuracy (TA) are evaluated as those of the CFR product by evaluating solar irradiances derived both from in-situ observations (direct measurements of solar irradiance obtained from the Baseline Surface Radiation Network (BSRN) and other in-situ networks) and satellite observations (derived using cloud flag and cloud fraction products). Climatology of cloud fraction obtained from ISCCP ${ }^{6)}$ and those from ground based sky-camera images are also used for supplemental evaluations. RT of CLTT and CLTH is indirectly evaluated through the calibration of SGLI TIR channels and also by comparing with objective analysis meteorological data of atmospheric temperature profile provided by Japan Meteorological Agency (JMA). On the other hand, SA and TA of CLTT and CLTH are evaluated using remotely sensed GVs obtained through in-situ observations and other airborne- and satellite observations. RT of COTW and CERW is evaluated with other satellite products, while SA is indirectly evaluated as cloud liquid water (CLW) derived both from in-situ observation (microwave radiometer etc.) and satellite observations (taking into account the SGLI-derived COTW 
and CERW). TA of COTW and CERW is evaluated by the same approach with the SA and also by comparing directly with in-situ observed cloud optical thickness (COT) by sky-radiometer. Finally, RT of COTI is evaluated with other satellite products, while SA and TA are evaluated using in-situ measured COT by sky-radiometer.

\subsection{Ocean}

There are seven standard ocean GVs consisting of three radiometric products (normalized water leaving radiance (NWLR), atmospheric correction parameter (AOT at VN7 and VN10), and photosynthetically available radiation (PAR)), three biogeochemical/bio-optical products (chlorophyll- $a$ concentration (CHLA), total suspended matter concentration (TSM), and colored dissolved organic matter (CDOM)), and a thermal product (sea surface temperature (SST)). All of these ocean GVs, which have been handed down from ADEOS-II/GLI mission to GCOM-C/SGLI, are indispensable products for studying carbon cycle in the ocean.

Validations of these ocean GVs are planned to be conducted primarily through the comparison with in-situ data. Supplementary similar GVs derived from other satellite data are also used for assessing relative quality of SGLI products. While in-situ data for SST validation obtained using buoys and ships in various ocean all over the world are available through the online near-real time in-situ Quality Monitor (iQuam; http://www.star.nesdis.noaa.gov/sod/sst/iquam/) developed at NESDIS, ${ }^{7)}$ validation data for other ocean GVs have to be acquired by ship cruises. In addition, when evaluating the achievement of RTs, accuracies of in-water $\mathrm{GVs}$ are defined for offshore ocean. Within the one year after the launch of GCOM-C, the availability of in-situ data particularly acquired at the offshore ocean sites could be very limited. Therefore, not only the validation with in-situ in-water data but also the comparison with the products of other satellites will be important for assessing the quality of SGLI products for the RT evaluations.

\subsection{Cryosphere}

There are four cryosphere GVs defined as SGLI standard products, essentially all of which have been handed down from the ADEOS-II/GLI mission. Snow and ice covered area (SICE) and Okhotsk sea-ice distribution (OKID) are the products for showing the areal distributions of snow and ice, while snow and ice surface temperature (SIST) and snow grain size of shallow layer (SGSL) are physical properties of snow and ice surface characterizing the longwave and shortwave radiative properties of the surface.

RT evaluations of the cryosphere GVs except for the areal products of SICE and OKID are basically conducted through the comparison with similar GV products derived from other satellites or climatological data, because the chance of the acquisitions of in-situ data particularly of snow grain size over remote snow and ice fields in the cryosphere is quite limited during the one year after the launch of GCOM-C satellite. For the SA and TA evaluations five years after the launch, we will use in-situ acquired data for the validation. For the validation of SICE, in-situ snow depth data available on-line through global meteorological station networks such as Global Historical Climatology Network-Daily (GHCND) provided by
NOAA/NCDC ${ }^{8)}$ will be used together with other satellite images including high resolution sensors such as Landsat-8/OLI and Sentinel-2/MSI. Accuracy of OKID will be evaluated through the comparison with high resolution satellite images from e.g., MODIS, VIIRS and other high resolution sensors. In addition, aerial photographs provided by the Japan Coast Guard will be used to assess the reliability of the product for practical uses. As for the SIST validation, in-situ snow surface temperature which is derived from the radiometer data of automatic weather stations (AWS) installed on the Greenland ice sheet ${ }^{9)}$ and other available BSRN AWS stations will be used together with in-situ data acquired by campaign observations. Finally, the evaluations of SGSL will use in-situ acquired snow grain size and the optical measurement data. The former is the grain size determined with microscopic observations at the ground sites, while the latter is the optically-equivalent grain size converted from the snow reflectance measured with spectrometers or the specific surface area (SSA) measured with an integrating sphere device at the sites in Hokkaido, Greenland, Svalbard and Antarctica. The relation between the physical ice particle size and the optically-equivalent grain size derived from the spectrometer data has been verified in the past study. ${ }^{10)}$

\section{GCOM-C Validation Monitor Web}

To monitor the temporal variation of the accuracies of the retrieved GVs, we have been developing an automated system for the validation of several GCOM-C products (the GCOM-C Validation web). ${ }^{11)}$ Currently, the systems for monitoring temporal variations of LTOA, SST, NWLR, LST, SICE, and SIST and for estimating the accuracies of LST, AOT, CLFG, COTW/CERW, COTI, and SIST have been developed and being tested on the web using MODIS-derived GVs available at JASMES. ${ }^{12)}$ The validation web is still a prototype and will be opened to the public after the launch of GCOM-C satellite. Figs. 1(a) and 1(b) show an analysis result of the temporal stability of satellite-derived SST and a scatter plot showing the accuracies of satellite-derived SST determined with in-situ data obtained from the iQuam. Figures 2 and 3 show another example of scatter plots for evaluating accuracies of AOT and SIST. These are still preliminary results before quality assurance. After the GCOM-C launch, actual SGLI data will be used as the satellite data source and the accuracies of the SGLI-derived GVs will be monitored on the Validation web.

\section{Summary and Conclusions}

Multiple geophysical variables ranging from land vegetation, atmospheric aerosol and clouds, marine ecosystem to remote polar snow and ice are planned to be retrieved from SGLI-observed multi-spectral radiances after the launch of GCOM-C satellite in 2017. We have been establishing validation strategy and field campaign sites for evaluating the accuracies of the wide variety of the SGLI geophysical variables. The quality of SGLI products are evaluated primarily through the comparison with in-situ acquired geophysical variables and secondarily using climatological data and/or similar geophysical variables derived from other 
satellites. During the one-year after the launch, the number of in-situ data can be quite limited. Therefore, the data from other satellites and climatology will be useful. On the other hand, acquisitions of in-situ data are key toward the final evaluations of the standard and goal accuracies five years after the launch of GCOM-C. Therefore, we will continue to make efforts to explore available in-situ data for the validation.
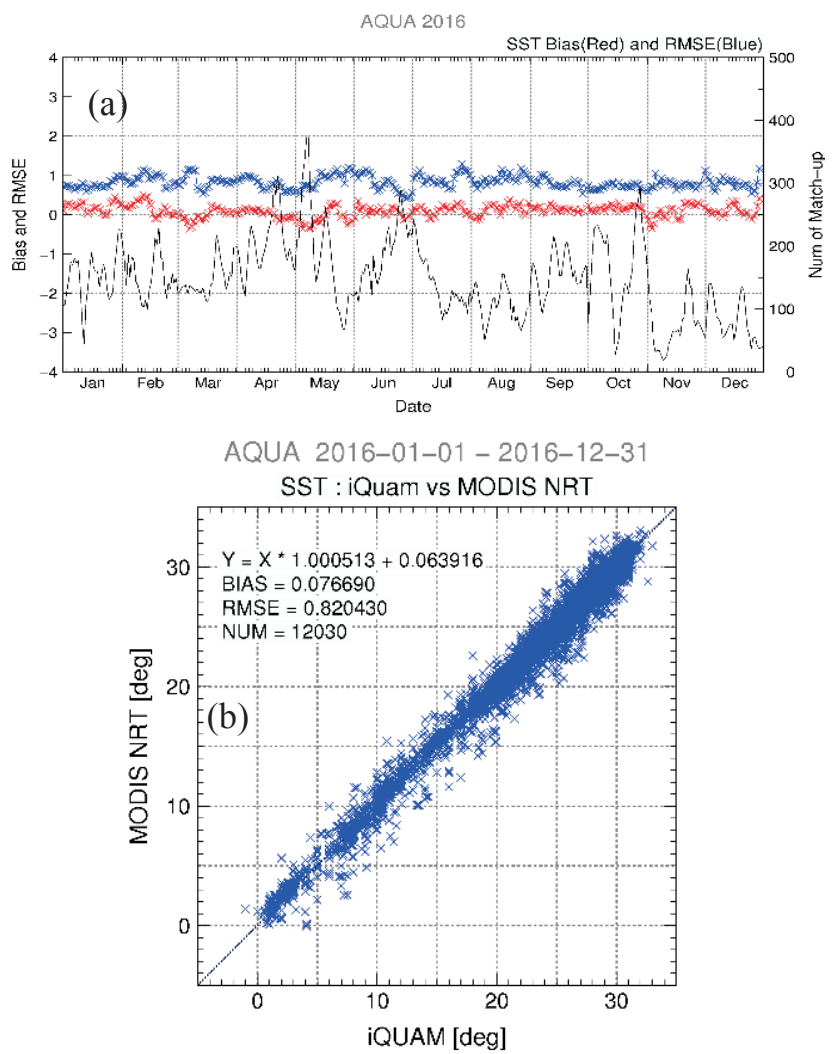

Fig. 1. (a) Temporal variations of bias (red line) and root mean square error (RMSE, blue line) of satellite-derived SST together with the number of in-situ data (black line) used for the bias estimations, (b) the scatter plot between in-situ acquired and satellite-derived SST. All the in-situ data were obtained from the iQuam ${ }^{7)}$ while the satellite data were from JASMES. ${ }^{11}$

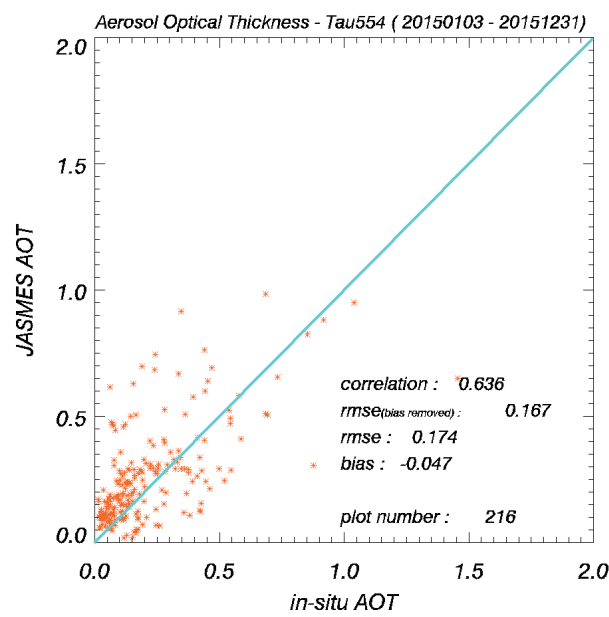

Fig. 2. A tentative comparison of AOTs at the wavelength of $554 \mathrm{~nm}$ obtained from in-situ acquired AOT at SKYNET ${ }^{4)}$ Chiba site and satellite-derived AOT from JASMES. ${ }^{11)}$

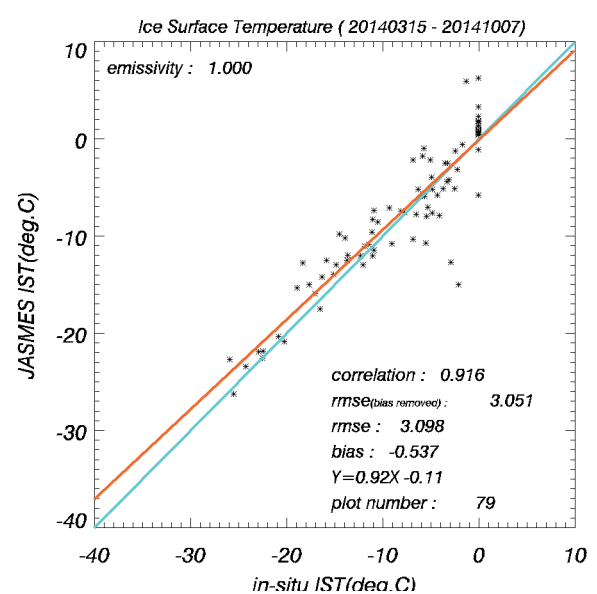

Fig. 3. A tentative comparison between in-situ acquired SIST and satellite-derived SIST. The in-situ data were obtained from the AWS of SIGMA-B ${ }^{9)}$ while the satellite-derived SIST were from JASMES. ${ }^{11)}$

\section{References}

1) Imaoka, K., Kachi, M., Fujii, H., Murakami, H., Hori, M., Ono, A., Igarashi, T., Nakagawa, K., Oki, T., Honda, Y., and Shimoda, H.: Global Change Observation Mission (GCOM) for Monitoring Carbon, Water Cycles, and Climate Change, Proc. IEEE, 98 (2010), pp. 717-734.

2) GCOM-C Web, http://suzaku.eorc.jaxa.jp/GCOM_C/index.html (accessed June 6, 2017).

3) Akitsu, T., Nishida Nasahara, K., Kobayashi, H., Saigusa, N., Hayashi, M., Nakaji, T., Kobayashi, H., Okano, T., and Honda, Y.: JAXA Super Sites 500: Large-Scale Ecological Monitoring Sites for Satellite Validation in Japan, Geoscience and Remote Sensing Symposium (IGARSS), 2015 IEEE International, 26-31 July 2015, pp. 3866-3869.

4) SKYNET Web, http://atmos2.cr.chiba-u.jp/skynet/index.html (accessed June 13, 2017).

5) Holben B. N., Eck, T. F., Slutsker, I., Tanre, D., Buis, J. P., Setzer, A., Vermote, E., Reagan, J. A., Kaufman, Y., Nakajima, T., Lavenu, F., Jankowiak, I., and Smirnov, A.: AERONET - A Federated Instrument Network and Data Archive for Aerosol Characterization, Remote. Sens. Environ., 66 (1998), pp. 1-16.

6) Rossow, W. B. and Schiffer, R. A.: Advances in Understanding Clouds from ISCCP, Bull. Am. Meteorol. Soc., 80 (1999), pp. 2261-2287.

7) Xu, F. and Ignatov, A.: In Situ SST Quality Monitor (iQuam), J. Atmos. Ocean. Technol., 31 (2014), pp. 164-180.

8) Menne, M. J., Durre, I., Vose, R. S., Gleason, B. E., and Houston, T. G.: An Overview of the Global Historical Climatology Network-Daily Database. J. Atmos. Ocean. Technol., 29 (2012), pp. $897-910$

9) Aoki, T., Matoba, S., Yamaguchi, S., Fujita, K., Yamasaki, T., Tanikawa, T., Niwano, M., Tsushima, A., Kuchiki, K., and Motoyama, H.: SIGMA-AWS Dataset, 1.00, Arctic Data Archive System (ADS), Japan, (2014) https://ads.nipr.ac.jp/dataset/A20140714-002 (accessed June 6, 2017).

10) Aoki, T., Aoki, T., Fukabori, M., Hachikubo, A., Tachibana, Y., and Nishio, F.: Effects of Snow Physical Parameters on Spectral Albedo and Bidirectional Reflectance of Snow Surface, J. Geophys. Res., 105 (2000), pp. 10219-10236.

11) GCOM-C Validation Web (currently access limited to GCOM-C PIs), http://kuroshio.eorc.jaxa.jp/JASMES/Validation/index.html (accessed June 6, 2017).

12) JAXA Satellite Monitoring for Environmental Studies (JASMES), http://kuroshio.eorc.jaxa.jp/JASMES/index.html (accessed June 6, 2017). 
Trans. JSASS Aerospace Tech. Japan Vol. 16, No. 3 (2018)

Table 2. Accuracy targets of SGLI Leve-2 products and validation data sources.

\begin{tabular}{|c|c|c|c|c|c|}
\hline Area & Product name $\left[\mathrm{ID}^{* 1}\right]$ & $\begin{array}{l}\text { Release } \\
\text { threshold }^{* 2}(\mathrm{RT})\end{array}$ & $\begin{array}{l}\text { Standard } \\
\text { accuracy }^{* 2}(\mathrm{SA})\end{array}$ & $\begin{array}{l}\text { Target } \\
\text { accuracy }^{* 2} \text { (TA) }\end{array}$ & Validation data sources \\
\hline \multirow{8}{*}{ 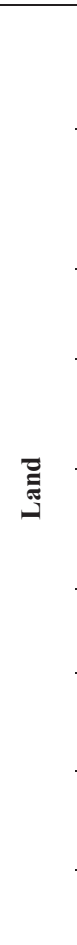 } & $\begin{array}{l}\text { Precise geometric } \\
\text { corrected radiance } \\
\text { [LTOA] }\end{array}$ & $<1$ pixel & $<0.5$ pixel & $<0.25$ pixel & $\begin{array}{l}\text { - GCP database derived from AVNIR-2 } \\
\text { etc. }\end{array}$ \\
\hline & $\begin{array}{l}\text { Atmospheric corrected } \\
\text { reflectance } \\
{[\mathrm{RSRF}]}\end{array}$ & $0.3(<=443 \mathrm{~nm})$ & $0.1(<=443 \mathrm{~nm})$ & $0.05(<=443 \mathrm{~nm})$ & - In-situ observation \\
\hline & $\begin{array}{l}\text { Vegetation index } \\
\text { [VGI_(NDVI/EVI_)] }\end{array}$ & $\begin{array}{l}\text { Grass:25\% (scene), } \\
\text { forest:20\% (scene) }\end{array}$ & $\begin{array}{l}\text { Grass:20\% (scene), } \\
\text { forest: } 15 \% \text { (scene) }\end{array}$ & $\begin{array}{l}\text { Grass: } 10 \% \text { (scene), } \\
\text { forest: } 10 \% \text { (scene) }\end{array}$ & $\begin{array}{l}\text { - In-situ observation } \\
\text { - Other Sat. (MODIS, VIIRS etc.) }\end{array}$ \\
\hline & $\begin{array}{l}\text { Above-ground biomass } \\
\text { [AGB_] }\end{array}$ & $\begin{array}{l}\text { Grass: } 50 \%, \\
\text { forest: } 100 \%\end{array}$ & Grass:30 \%, forest:50 \% & $\begin{array}{l}\text { Grass: } 10 \%, \\
\text { forest: } 20 \%\end{array}$ & $\begin{array}{l}\text { - In-situ obs.@0.25 km² sites } \\
\text { - Other Sat. (MOLI, GEDI, PALSAR2, } \\
\text { other SARs etc.) }\end{array}$ \\
\hline & $\begin{array}{l}\text { Shadow index } \\
\text { [VGI_(SDI_)] }\end{array}$ & $\begin{array}{l}\text { Grass: } 30 \% \text { (scene) } \\
\text { forest: } 30 \% \text { (scene) }\end{array}$ & $\begin{array}{l}\text { Grass \& forest:20\% } \\
\text { (scene) }\end{array}$ & $\begin{array}{l}\text { Grass \&forest: } 10 \% \\
\text { (scene) }\end{array}$ & $\begin{array}{l}\text { - In-situ obs.@0.25 km² sites } \\
\text { - Other Sat. (MODIS, VIIRS etc.) }\end{array}$ \\
\hline & $\begin{array}{l}\text { Fraction of absorbed PAR } \\
\text { [LAI_(FPAR)] }\end{array}$ & $\begin{array}{l}\text { Grass:50\%, } \\
\text { forest: } 50 \%\end{array}$ & Grass:30 \%, forest:20 \% & $\begin{array}{l}\text { Grass:20\%, } \\
\text { forest: } 10 \%\end{array}$ & $\begin{array}{l}\text { - In-situ obs.@0.25 km² sites } \\
\text { - Other Sat. (MODIS, VIIRS etc.) }\end{array}$ \\
\hline & $\begin{array}{l}\text { Leaf area index } \\
\text { [LAI_] }\end{array}$ & $\begin{array}{l}\text { Grass: } 50 \%, \\
\text { forest: } 50 \%\end{array}$ & Grass:30 \%, forest:30 \% & $\begin{array}{l}\text { Grass: } 20 \%, \\
\text { forest:20\% }\end{array}$ & $\begin{array}{l}\text { - In-situ obs.@0.25 km² sites } \\
\text { - Other Sat. (MODIS, VIIRS etc.) }\end{array}$ \\
\hline & $\begin{array}{l}\text { Land surface temperature } \\
\text { [LST_] }\end{array}$ & $<3.0 \mathrm{~K}$ (scene) & $<2.5 \mathrm{~K}$ (scene) & $<1.5 \mathrm{~K}$ (scene) & $\begin{array}{l}\text { - In-situ obs.@0.25 km² sites } \\
\text { - Other Sat. (MODIS, VIIRS etc.) }\end{array}$ \\
\hline \multirow{7}{*}{ 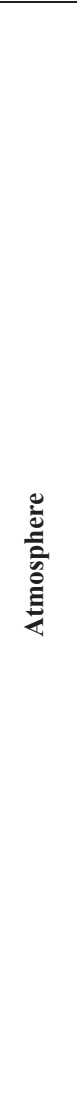 } & $\begin{array}{l}\text { Cloud flag/ Classification } \\
{[\text { CLFG] }}\end{array}$ & $\begin{array}{l}10 \% \text { (with whole-sky } \\
\text { camera) }\end{array}$ & \multicolumn{2}{|c|}{$\begin{array}{l}\text { (Evaluated as the classified cloud fraction } \\
\text { product) }\end{array}$} & $\begin{array}{l}\text { - Cloud amount from sky-camera based } \\
\text { on BI-SI method, }\end{array}$ \\
\hline & $\begin{array}{l}\text { Cloud top temp/height } \\
\text { [CLPR (CLTT/CLTH)] }\end{array}$ & $1 \mathrm{~K}^{* \mathrm{~A} 2}$ & $\begin{array}{l}3 \mathrm{~K} / 2 \mathrm{~km} \\
\text { (top temp/height) }^{* \mathrm{~A} 3}\end{array}$ & $\begin{array}{l}1.5 \mathrm{~K} / 1 \mathrm{~km} \\
\text { (temp/height) }\end{array}$ & $\begin{array}{l}\text { - Cal. of TIR bands \& JMA Objective } \\
\text { analysis data (for RT) } \\
\text { - RS data from ground, airborne, and } \\
\text { other satellites (lidar, radar, radiometer } \\
\text { (for SA \& TA) }\end{array}$ \\
\hline & $\begin{array}{l}\text { Water cloud OT/ effective } \\
\text { radius } \\
{[\text { CLPR }(\mathrm{COTW} / \mathrm{CERW})]}\end{array}$ & $\begin{array}{l}10 \% / 30 \% \\
\text { (Cloud OT/radius) }^{* \mathrm{~A} 4}\end{array}$ & $\begin{array}{l}100 \% \\
\text { (as cloud liquid water }{ }^{*} \text { A5) }\end{array}$ & $50 \%{ }^{* \mathrm{~A} 5} / 20 \%{ }^{* \mathrm{~A} 6}$ & $\begin{array}{l}\text { - Other Sat. (MODIS, VIIRS etc. for RT) } \\
\text { - In-situ obs. of COT by Skynet } \\
\text { sky-radiometer (for TA) }\end{array}$ \\
\hline & $\begin{array}{l}\text { Ice cloud optical thickness } \\
\text { [CLPR (COTI)] }\end{array}$ & $30 \%{ }^{* \mathrm{~A} 4}$ & $70 \%{ }^{* \mathrm{~A} 6}$ & $20 \%{ }^{* \mathrm{~A} 6}$ & $\begin{array}{l}\text { - In-situ obs. of COT by Skynet } \\
\text { sky-radiometer } \\
\text { - Other Sat. (MODIS, VIIRS etc.) }\end{array}$ \\
\hline & $\begin{array}{l}\text { Aerosol over the ocean } \\
{[\text { ARNP }(\mathrm{AOTO} / \mathrm{AAEO})]}\end{array}$ & $\begin{array}{l}0.1 \\
\left.\text { (Monthly } \tau \_670,865\right)^{* A 7}\end{array}$ & $\begin{array}{l}0.1 \\
\left(\text { scene } \tau \_670,865\right)^{* \mathrm{~A} 7}\end{array}$ & $\begin{array}{l}0.05 \\
\left.\text { (scene } \tau_{-} 670,865\right)\end{array}$ & $\begin{array}{l}\text { - In-situ obs. of AOT by Skynet \& } \\
\text { AERONET sky-radiometer } \\
\text { - Other Sat. (MODIS, VIIRS etc.) }\end{array}$ \\
\hline & $\begin{array}{l}\text { Land aerosol by near ultra } \\
\text { violet } \\
{[\text { ARNP (AOTL/AAEL)] }}\end{array}$ & $\begin{array}{l}0.15 \\
\left(\text { Monthly } \tau_{-} 380\right)^{* \mathrm{~A} 7}\end{array}$ & $\begin{array}{l}0.15 \\
\left(\text { scene } \tau \_380\right)^{* \mathrm{~A} 7}\end{array}$ & $\begin{array}{l}0.1 \\
\left.\text { (scene } \tau \_380\right)\end{array}$ & $\begin{array}{l}\text { - In-situ obs. of AOT by Skynet \& } \\
\text { AERONET sky-radiometer } \\
\text { - Other Sat. (MODIS, VIIRS etc.) }\end{array}$ \\
\hline & $\begin{array}{l}\text { Aerosol by Polarization } \\
\text { [ARPL } \\
\text { (AOTP/AAEP/ASSA)] }\end{array}$ & $\begin{array}{l}0.15 \\
\left(\text { Monthly } \tau \_670,865\right)^{* A 7}\end{array}$ & $\begin{array}{l}0.15 \\
\left(\text { scene } \tau \_670,865\right)^{* \mathrm{~A} 7}\end{array}$ & $\begin{array}{l}0.1 \\
\left.\text { (scene } \tau_{-} 670,865\right)\end{array}$ & $\begin{array}{l}\text { - In-situ obs. of AOT by Skynet \& } \\
\text { AERONET sky-radiometer } \\
\text { - Other Sat. (MODIS, VIIRS etc.) }\end{array}$ \\
\hline ర్లّँ & $\begin{array}{l}\text { Normalized water leaving } \\
\text { radiance } \\
{[\mathrm{NWLR}(\mathrm{L} * * *)]} \\
* * * \text { is wavelength. }\end{array}$ & $\begin{array}{l}60 \% \\
(443 \sim 565 \mathrm{~nm})\end{array}$ & $\begin{array}{l}50 \%(<600 \mathrm{~nm}) \\
0.5 \mathrm{~W} / \mathrm{m}^{2} / \mathrm{str} / \mu \mathrm{m} \\
(>600 \mathrm{~nm})\end{array}$ & $\begin{array}{l}0.25 \mathrm{~W} / \mathrm{m}^{2} / \mathrm{str} / \mu \mathrm{m} \\
(>600 \mathrm{~nm})\end{array}$ & $\begin{array}{l}\text { - In-situ observation } \\
\text { - Temporal variation of SGLI nLw } \\
\text { - Other Sat. (MODIS, VIIRS etc.) }\end{array}$ \\
\hline
\end{tabular}


Trans. JSASS Aerospace Tech. Japan Vol. 16, No. 3 (2018)

\begin{tabular}{|c|c|c|c|c|c|}
\hline & $\begin{array}{l}\text { Atmospheric correction } \\
\text { parameters } \\
{\left[\mathrm{NWLR}\left(\mathrm{T}^{* * *}\right)\right]} \\
* * * \text { is wavelength. }\end{array}$ & $\begin{array}{l}80 \% \\
(\mathrm{AOT} @ 865 \text { nm) }\end{array}$ & $\begin{array}{l}50 \% \\
(\mathrm{AOT} @ 865 \mathrm{~nm})\end{array}$ & $\begin{array}{l}30 \% \\
(\mathrm{AOT} @ 865 \mathrm{~nm})\end{array}$ & $\begin{array}{l}\text { - In-situ observation } \\
\text { - Other Sat. (MODIS, VIIRS etc.) }\end{array}$ \\
\hline & $\begin{array}{l}\text { Photosynthetically } \\
\text { available radiation } \\
\text { [NWLR (PAR_)] }\end{array}$ & $\begin{array}{l}20 \% \\
(10 \mathrm{~km} / \mathrm{month})\end{array}$ & $\begin{array}{l}15 \% \\
(10 \mathrm{~km} / \mathrm{month})\end{array}$ & $\begin{array}{l}10 \% \\
(10 \mathrm{~km} / \mathrm{month})\end{array}$ & $\begin{array}{l}\text { - In-situ observation } \\
\text { - Other Sat. (MODIS, VIIRS etc.) }\end{array}$ \\
\hline & $\begin{array}{l}\text { Chlorophyll-a } \\
\text { concentration } \\
\text { [IWPR (CHLA)] }\end{array}$ & $\begin{array}{l}-60 \sim+150 \% \\
\text { (offshore) }\end{array}$ & $-60 \sim+150 \%$ & $\begin{array}{l}-35 \sim+50 \% \\
\text { (offshore), } \\
-50 \sim+100 \% \\
\text { (coast) }\end{array}$ & $\begin{array}{l}\text { - In-situ observation } \\
\text { - Other Sat. (MODIS, VIIRS etc.) }\end{array}$ \\
\hline & $\begin{array}{l}\text { Suspended solid } \\
\text { concentration } \\
\text { [IWPR (TSM_)] }\end{array}$ & $\begin{array}{l}-60 \sim+150 \% \\
\text { (offshore) }\end{array}$ & $-60 \sim+150 \%$ & $-50 \sim+100 \%$ & $\begin{array}{l}\text { - In-situ observation } \\
\text { - Other Sat. (MODIS, VIIRS etc.) }\end{array}$ \\
\hline & $\begin{array}{l}\text { Colored dissolved organic } \\
\text { matter } \\
{[\text { IWPR }(\mathrm{CDOM})]}\end{array}$ & $\begin{array}{l}-60 \sim+150 \% \\
\text { (offshore) }\end{array}$ & $-60 \sim+150 \%$ & $-50 \sim+100 \%$ & $\begin{array}{l}\text { - In-situ observation } \\
\text { - Other Sat. (MODIS, VIIRS etc.) }\end{array}$ \\
\hline & $\begin{array}{l}\text { Sea surface temperature } \\
{\left[\mathrm{SSTD} / \mathrm{SSTN}\left(\mathrm{SST}_{-}\right)\right]}\end{array}$ & $\begin{array}{l}0.8 \mathrm{~K} \\
\text { (daytime) }\end{array}$ & $\begin{array}{l}0.8 \mathrm{~K} \\
\text { (day \& night time) }\end{array}$ & $\begin{array}{l}0.6 \mathrm{~K} \\
\text { (day \& night time) }\end{array}$ & $\begin{array}{l}\text { - In-situ SST from iQuam } \\
\text { - In-situ observation } \\
\text { - Other Sat. (MODIS, VIIRS etc.) }\end{array}$ \\
\hline \multirow{4}{*}{ 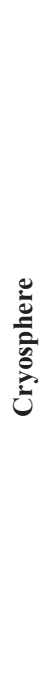 } & $\begin{array}{l}\text { Snow and Ice covered area } \\
\text { [SICE] }\end{array}$ & $\begin{array}{l}10 \% \\
\text { (vicarious val. with } \\
\text { other sat. data) }\end{array}$ & $7 \%$ & $5 \%$ & $\begin{array}{l}\text { - DCDF snow depth only over land } \\
\text { - Other Sat. (MODIS, VIIRS, OLI etc.) }\end{array}$ \\
\hline & $\begin{array}{l}\text { Okhotsk sea-ice } \\
\text { distribution } \\
\text { [OKID] }\end{array}$ & & $5 \%$ & $3 \%$ & $\begin{array}{l}\text { - Other Sat. (MODIS, VIIRS, OLI etc.) } \\
\text { - Photos etc. (Aerial photos, hand-drawn } \\
\text { ice map) }\end{array}$ \\
\hline & $\begin{array}{l}\text { Snow and ice surface } \\
\text { Temperature } \\
{[\text { SIPR (SIST)] }}\end{array}$ & $\begin{array}{l}5 \mathrm{~K} \\
\text { (vicarious val. with } \\
\text { other satellite data and } \\
\text { climatology) }\end{array}$ & $2 \mathrm{~K}$ & $1 \mathrm{~K}$ & $\begin{array}{l}\text { - Ts from SIGMA, BSRN AWS@ } \\
\text { Greenland, Dome-C etc. } \\
\text { - In-situ obs.@Greenland, Hokkaido, } \\
\text { Svalbard etc. (Campaign) } \\
\text { - Other Sat. (MODIS, VIIRS, OLI etc.) }\end{array}$ \\
\hline & $\begin{array}{l}\text { Snow grain size of } \\
\text { shallow layer } \\
{[\text { SIPR (SGSL)] }}\end{array}$ & $\begin{array}{l}100 \% \\
\text { (vicarious val. with } \\
\text { climatology between } \\
\text { Temperature and snow } \\
\text { grain size) }\end{array}$ & $50 \%$ & $30 \%$ & $\begin{array}{l}\text { - Vicarious Val. with Climatology of } \\
\text { Temp-Grain size relation (for RT) } \\
\text { - Auto-Optical Measurements @ } \\
\text { Hokkaido, Svalbard etc. } \\
\text { - In-situ obs. @Greenland, Hokkaido, } \\
\text { Svalbard etc. (Campaign) } \\
\text { - Other Sat. (MODIS, VIIRS, OLI etc.) }\end{array}$ \\
\hline
\end{tabular}

\section{Common notes:}

*1: Product ID of Leve-2 product is written in [ ] and Level-3 is written in ( ).

*2: The accuracy thresholds are defined for each mission success level. The "release threshold" is the minimum level for the first data release at one year from launch. The "standard" and "goal" accuracies correspond to full- and extra success criteria of the mission respectively. Accuracies are basically shown by root mean square error (RMSE: Eq. (1)) with the unit of geophysical variables (GVs). However, the target accuracies written with the unit of percent (\%) except for flag-type products are defined as the ratio of RMSE and the average of in-situ observations (Eq. (2)). As for the flag-type products (e.g., CLFG), overall accuracies of the flag judgments are statistically evaluated using in-situ observation data.

$$
\begin{aligned}
& \mathrm{RMSE}_{\mathrm{GV}}[\mathrm{Unit} \text { of } \mathrm{GV}]=\left(1 / \mathrm{N}^{*} \Sigma(\mathrm{S}(i)-\mathrm{T}(i))^{2}\right)^{1 / 2} \\
& \mathrm{RMSE}_{\mathrm{GV}} / \mathrm{Ave}_{\text {in-situ }}[\%]=\left(1 / \mathrm{N}^{*} \Sigma(\mathrm{S}(i)-\mathrm{T}(i))^{2}\right)^{1 / 2} /\left(1 / \mathrm{N}^{*} \Sigma \mathrm{T}(i)\right) \times 100 \\
& \text { where } \mathrm{N} \text { is the number of observations, } \mathrm{S}(i) \text { is SGLI data, } \mathrm{T}(i) \text { is in-situ data. }
\end{aligned}
$$

\section{Land notes:}

*L1: Defined with land reflectance 0.2 , solar zenith<30 deg., and flat surface. Release threshold is defined with AOT@500 nm<0.25.

\section{Atmosphere notes:}

*A1: Comparison with in-situ observation on monthly 0.1-degree grid.

*A2: Vicarious validation on sea surface and comparison with objective analysis data.

*A3: Inter comparison with airplane remote sensing on water clouds of middle optical thickness.

*A4: Release threshold is defined by vicarious validation with other satellite data (e.g., global monthly statistics in the mid-low latitudes).

*A5: Comparison with cloud liquid water by in-situ microwave radiometer.

*A6: Comparison with optical thickness by sky-radiometer (the difference can be large due to time-space inconsistence and large error of the ground measurements).

*A7: Estimated by experience of aerosol products by GLI and POLDER. 